\title{
Conservation in the Sea: A Survey of Marine Parks
}

\author{
By John E. Randall
}

The idea of national parks and reserves in the sea has developed slowly, but the increasing popularity of underwater swimming, fishing and coral collecting makes it urgently necessary to protect marine life. Like their counterparts on land, marine parks are usually a great tourist attraction Kenya has recently created two - and a careful balance has to be achieved, with some areas reserved for tourists and others as sanctuaries where also scientific studies can be made.

$\mathbf{T}$ HERE are areas of great beauty in the sea as well as on land, but the idea of preserving them has been slow to develop. Yellowstone, the world's first national park in the modern sense, was established in 1872, but not until 1935 was an area of sea included within the jurisdiction of the US National Park Service. This was Fort Jefferson National Monument at Dry Tortugas, 65 miles west of Key West, created for the massive fortification, not the marine gardens; but as only 87 of the Monument's 47,125 acres consist of land it can be regarded as the first marine park. Even today only nine other regions administered by the US National Park Service include marine areas: these are five national seashores Assateague Island, Cape Cod, Fire Island, Padre Island and Point Reyes; two national monuments - Buck Island Reef and Glacier Bay; and two national parks - Everglades and the Virgin Islands. Others are under study for the inclusion of marine areas.*

It is not difficult to understand why marine parks have evolved so slowly. Only in the last few decades has man entered the sea for recreation on a large scale, with face masks and goggles, swim fins, and SCUBA for untethered breathing. Paradoxically his progress in conquering the more hostile environment above him is more advanced than that below the surface of the sea, and his ventures into space far excel his exploration of the sea in imagination, technology, and expenditure of funds. Unfortunately, there is a general feeling that the resources of the sea are so immense as to be virtually inexhaustible. This may be true for many mineral resources, but we now know that man's unregulated harvesting

\begin{abstract}
*These include Channel Islands National Monument off the coast of California, for which there is presently no oceanic jurisdiction, and which it is suggested should be enlarged to a national park taking in the islands of Santa Cruz, Santa Rosa, and San Miguel and surrounding waters. Other sites outside the park system in which the sea will play a dominant role have also been proposed, for example Biscayne National Monument suggested for the reefs just south of Miami and north of the Key Largo Reef Preserve (also known as the Pennecamp Coral Reef State Park), a noteworthy marine park, 21 miles long and 4 miles wide, established in 1960 and administered by the State of Florida.
\end{abstract}

The author is on the staff of the Hawaii Institute of Marine Biology, University of Hawaii, and the Bernice P. Bishop Museum in Honolulu. This paper, received in January 1968, is Contribution No. 318 of the Institute. 
has endangered the stocks of certain fish and other food organisms, particularly littoral forms. Another unfortunate attitude is to regard the oceans as convenient dumping places for any and all waste matter, from sewage to atomic wastes, an attitude applied also to our rivers and lakes, with even more disastrous effects. Some waste materials, such as plastic, that are resistant to deterioration are accumulating on the shores and sea bottom. An empty beer can in a marine garden is as offensive to the undersea viewer as it is in a garden on land. Gradually, however, public indignation about pollution has increased. A feeling for conservation is replacing this wanton exploitation, and one manifestation of this is the marine park, a concept that has been enthusiastically received by many nations in recent years, including some of the so-called underdeveloped countries.

The First World Conference on National Parks, in 1962 in Seattle, urged all countries to create marine parks or reserves. In 1963, among the resolutions of the Nairobi General Assembly of the International Union for Conservation of Nature and Natural Resources, were two commending the governments of the Sudan and Kenya for their intention to create marine national parks 'in the spirit of Recommendation No. 15 of the First World Conference on National Parks'.* Since then Kenya has established two parks, the Malindi ( $2 \frac{1}{4}$ square miles) and the Watamu ( $4 \frac{1}{2}$ square miles); the Sudan park is proposed 'for the shores of the Red Sea'.

One notable Red Sea marine park, inaugurated in 1959, is the Eilat Coral Nature Preserve, a 1200-metre coastal region off the Israeli port at the northern end of the Gulf of Aqaba, where all aquatic organisms are fully protected. Wardens with police powers survey the area constantly, and also guide visitors and instruct school children. Israel is planning two similar marine reserves on its Mediterranean coast, and on some of the virgin reefs of the newly acquired Sinai Peninsula the Society of Nature Preservation has already posted notices prohibiting fishing and the taking of corals and shells, although there is as yet no legal basis for such signs.

In South Africa a step in the direction of marine parks is the recent establishment of Tsitsikama National Park, a narrow strip of majestically

\footnotetext{
*The 15 th recommendation of the Seattle Conference stated:

'Whereas it is recognised that the oceans and their teeming life are subject to the same dangers of human interference and destruction as the land, that the sea and land are ecologically interdependent and indivisible, that population pressures will cause man to turn increasingly to the sea, and especially to the underwater scene, for recreation and spiritual refreshment, and that the preservation of unspoiled marine habitat is urgently needed for ethical and esthetic reasons, for the protection of rare species, for the replenishment of stocks and valuable food species, and for the provision of undisturbed areas for scientific research.

'The First World Conference on National Parks invites the governments of all those countries having marine frontiers, and other appropriate agencies, to examine as a matter of urgency the possibility of creating marine parks or reserves to defend underwater areas of special significance from all forms of human interference, and further recommends the extension of existing national parks and equivalent reserves with shorelines, into the water to the ten fathom depth or the territorial limit or some other appropriate off-shore boundary.'
} 


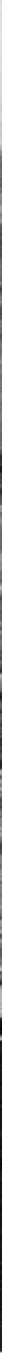

\section{CONSERVATION IN THE SEA}

Plate 7: Hanauma Bay, the most popular place in the Hawailan Islands for underwater swimmers, has been a marine life conservation district since 1967. Hawaii Visitors' Bureau 


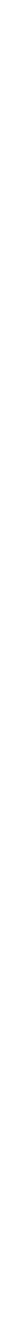




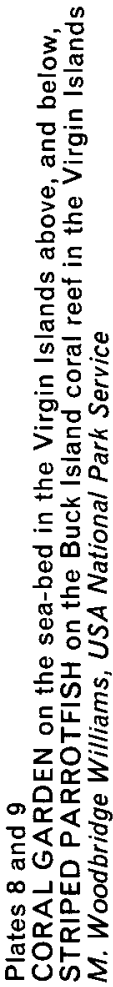
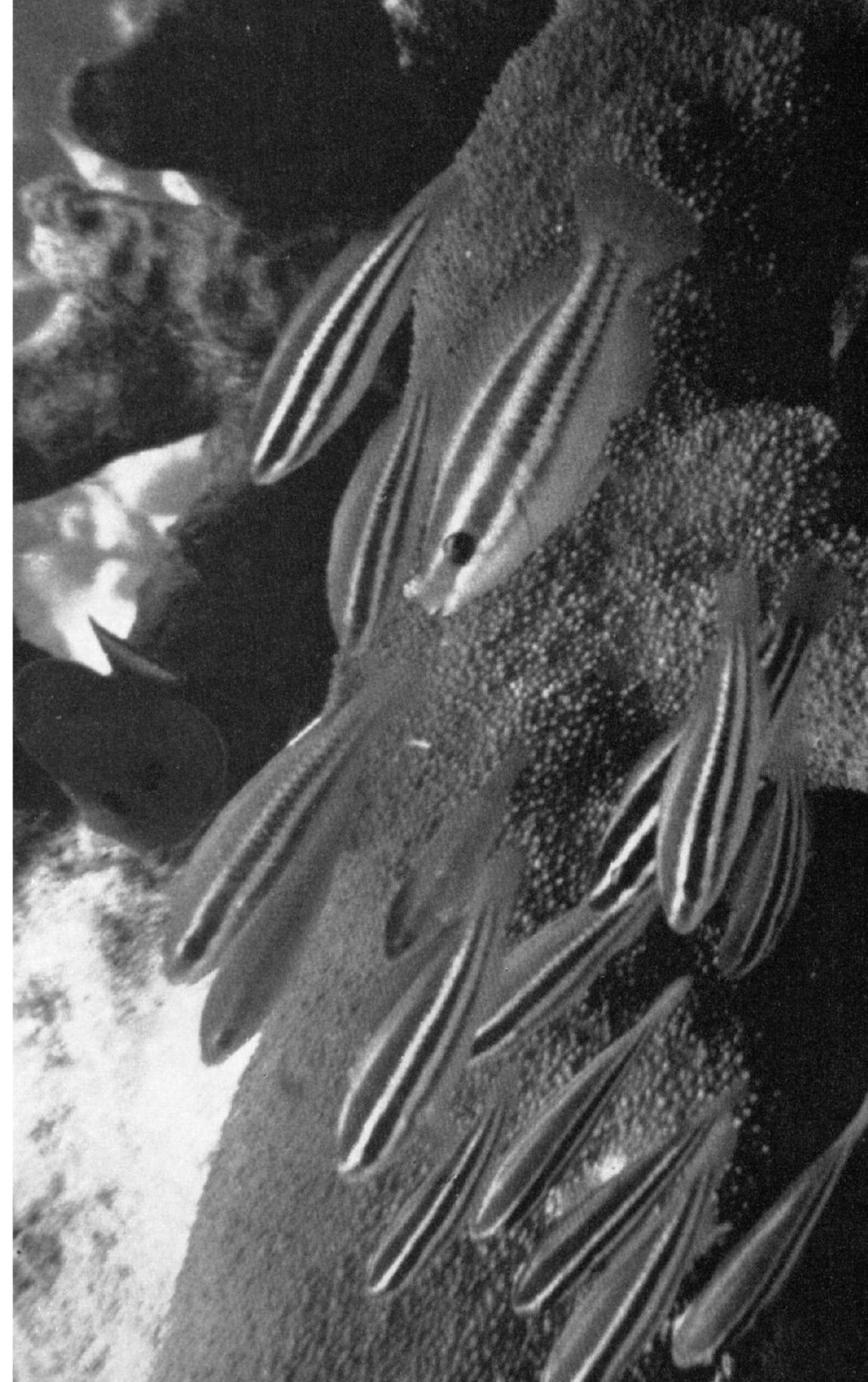


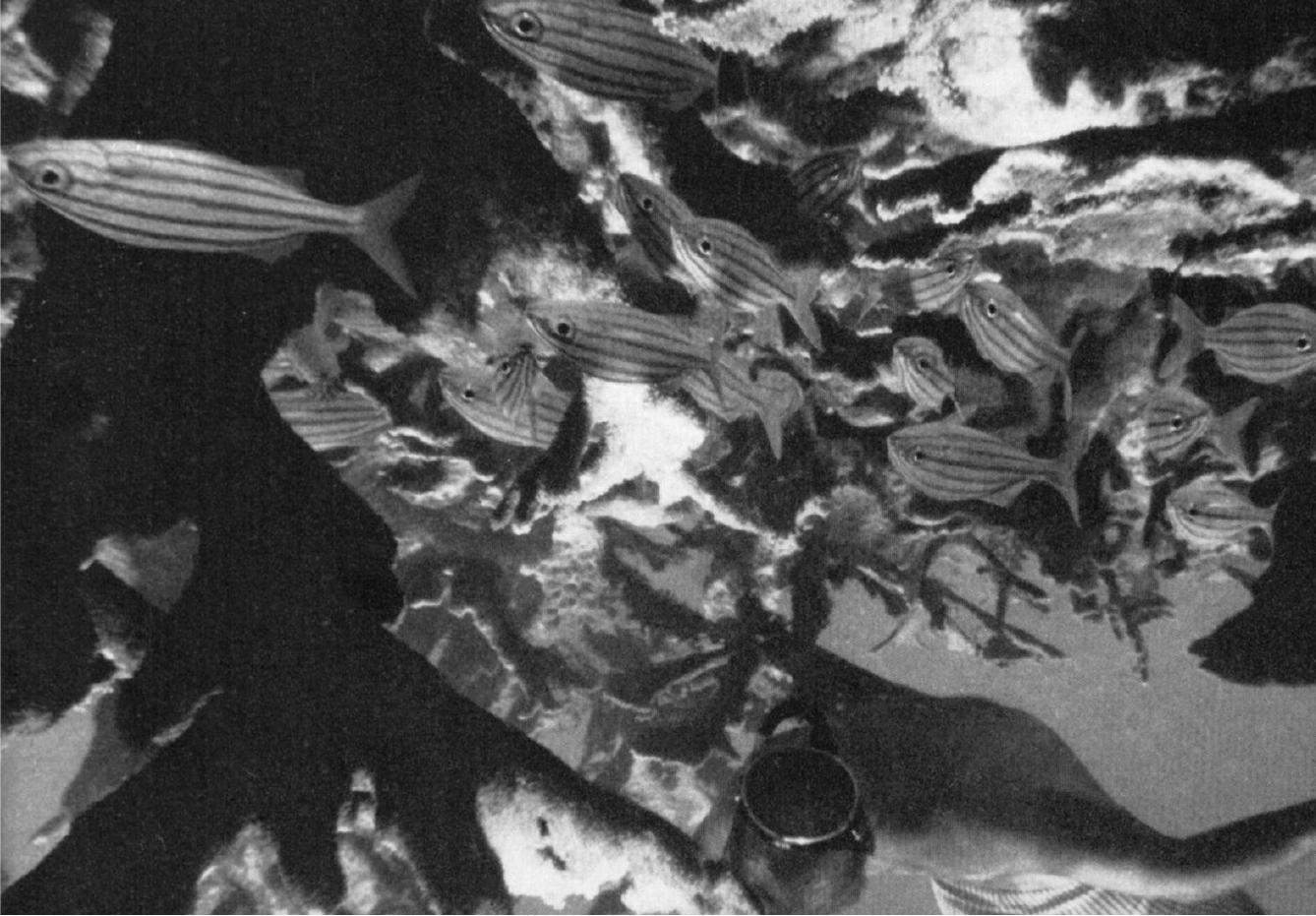

Plates $10-12$

FISH-WATCHER among elkhorn coral, above. Below, FOUR-EYED BUTTERFLY FISH and SMOOTH TRUNKFISH.

George Schesventer and M. Woodbridge Williams, USA NPS
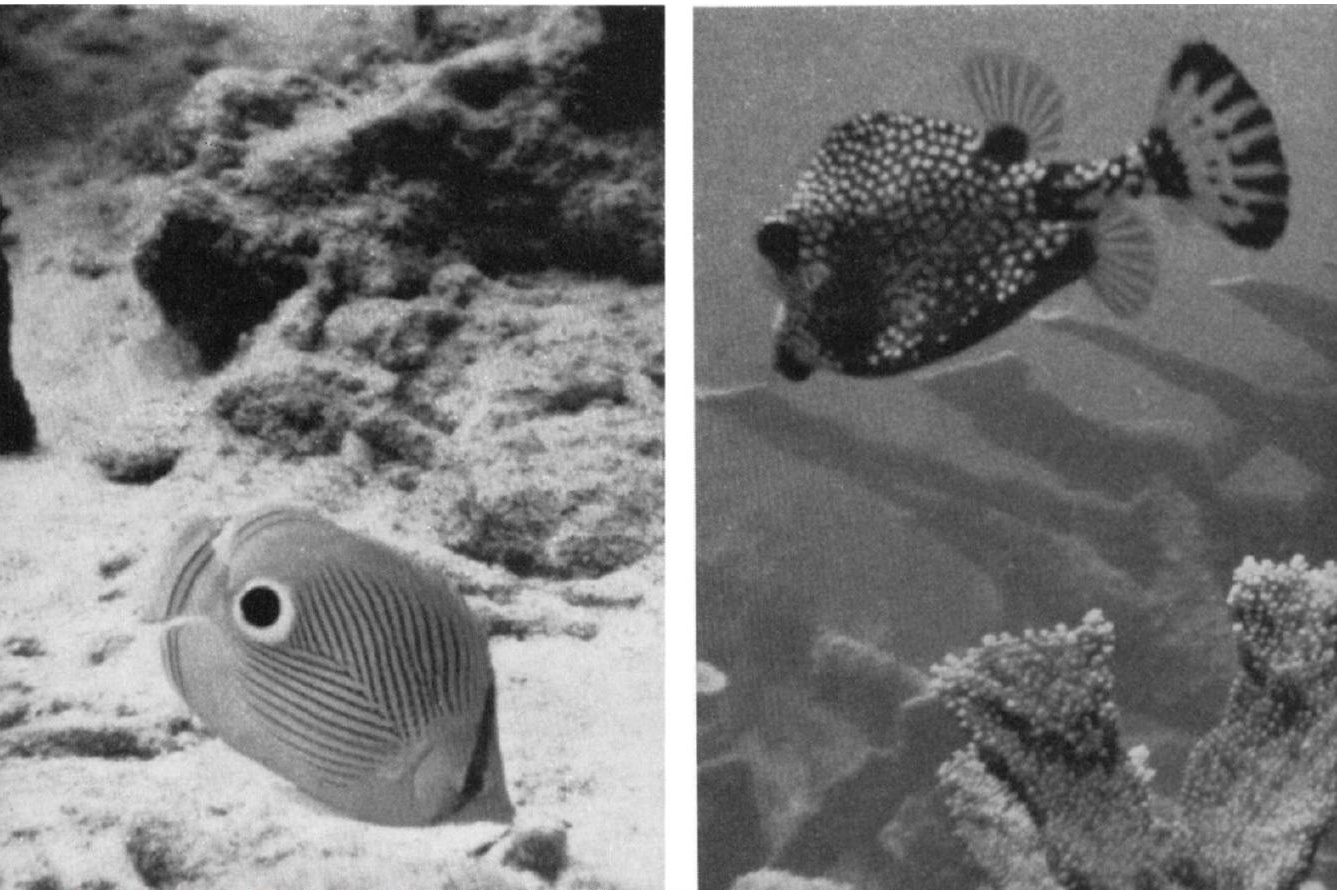

Heruesed I. org/10.1017/S003060530000764X Published online by Cambridge University Press abs 
scenic rocky coast. Here freshwater angling is restricted and, according to the late Professor J. L. B. Smith of Rhodes University, fishing restrictions are imminent. Spearfishermen are already prohibited from taking the kraaibek, a peculiar, very tame parrot-beaked fish.

In June 1966, the Lucerne IUCN General Assembly requested that the International Biological Programme, in collaboration with the IUCN, prepare as a matter of urgency a checklist of uninhabited islands which have unique or important animal or plant communities, with a view to their preservation as unspoiled natural areas.

\section{Symposium in Japan}

This was the background when, in September 1966, a Special Symposium on Marine Parks was held in Japan in conjunction with the Eleventh Pacific Science Congress. Dr Tuyosi Tamura, chairman of the Nature Conservation Society of Japan, and Dr Takashi Ino were the conveners, and Dr Harold J. Coolidge served as chairman at the two major conferences. About 150 people, mostly from countries bordering the Pacific, attended and some described developments in their countries. Drs Donald F. McMichael and Paul H. Fischer presented papers on marine parks in Australia.

Many of the islands along Australia's Great Barrier Reef, long recognised by the Queensland Government as a natural phenomenon of great scientific and tourist value, have been declared national parks under the Forestry Act; but the administration extends to the high tide mark only. In 1938 a notable exception was made of Green Island for which protection was extended to all marine organisms of the adjacent reef (except for fishes caught by rod or hand line with no more than two hooks and a limited number of small bait fishes taken by cast net; or those taken by marine biologists with special collecting permits). Similar protection was given to Heron Island, site of the Heron Island Research Station, and nearby Wistari Reef. Both islands have suffered from heavy tourist visitation, and protection was given when the government became aware of the serious damage spearfishermen, shell collectors, and coral seekers were doing. The taking of corals is now prohibited in all Queensland waters except by special licence in selected areas. There are also plans for surveys which might lead to the establishment of other marine reserves both in the Barrier Reef and other regions of Australia, and Mr A. Dunbavin Butcher reported that serious consideration is being given to the establishment of a marine national park in Victoria.

In the Philippines Dr Geogracias V. Villadolid described three parks which include marine areas: the Hundred Islands National Park at the western side of the Gulf of Lingayen, proclaimed in 1940; Manila Bay Beach Resort, established in 1954, and the shore and territorial waters from Agoo to Damortis, Pangasinin, started in 1962. Other sites should be included, such as Puerto Galera, Mindoro, where the marine station of the University of the Philippines is located, and Matabungkay Bay, in Luzon. Also legislation and enforcement are needed to stop the overexploitation of certain reef areas and destructive practices such as the use of dynamite or bleaching agents to obtain fishes. 
In Japan, about which Drs Seibin Arasaki, Takasi Tokioka, and Yaichiro Okada spoke, the government in 1965 authorised the National Parks Bureau to frame a system of marine parks, and it is expected that the first marine park will be established soon in waters adjoining one of the existing national parks. In heavily populated Japan, which depends so much on the sea for food, great care is necessary in setting up such parks, and it was suggested that commercial fishing for pelagic fishes might be permitted in a marine sanctuary since these fishes are only transients and not part of the bottom community. The Nature Conservation Society of Japan has published a booklet on plans for marine parks in Japan.

More than one marine station has all but lost its raison d'être because of pollution, shore alteration by dredging or filling, or by excessive collecting of marine organisms in its vicinity. Dr Isabella A. Abbott's report of California's progress was encouraging, for three marine refuges have been established in conjunction with marine laboratories operated by major universities of the state: the Hopkins, San Diego, and Bodega Marine Life Refuges. California also has special refuges which protect one or a few species such as waterfowl, sea otters, and even the lowly clam. The Pacific Grove Marine Gardens Fish Refuge was requested by the city of Pacific Grove in order to preserve its rich shore fauna and flora. Another category under California law is Point Lobos State Reserve Park at the south end of Carmel Bay, where no persons (except for a few with special permits) are allowed to take any animals, plants or rocks from the 340-acre headland areas; the sea around it, to a depth of about 20 metres, is also protected.

The Virgin Islands, discussed by the author, have two marine parks: the Virgin Islands National Park, on St John, and Buck Island Reef National Monument, off St Croix (Sea Frontiers, Vol 8, No 1). When initiated in 1959, the park on St John did not include any aquatic area; this was added later by Act of the Congress. The Exuma Cays Park, a 22-mile stretch of islands of the Exumas chain in the Bahamas was the first post World War II marine reserve in the Western Hemisphere (Sea Frontiers, Vol 4, No 2). The failure of the Commonwealth of Puerto Rico to establish a reserve for its famous Phosphorescent Bay and nearby coral reefs and mangrove islands (including Magueyes Island, the location of the field station of the Institute of Marine Biology of the University of Puerto Rico), despite valiant efforts by individuals and organisations, is disappointing. In this magnificent bay a delicate balance of nature enables luminescent dinoflagellates (Pyrodinium) to flourish to such an extent that at night the waters of the bay glow like greenish white fire when disturbed, as by the passage of a boat. Anything that upsets this balance such as a change in the use of the watershed, sewage, industrial pollution, or a deepening of the narrow inlet would probably eliminate or materially reduce the phosphorescence. The US Department of the Interior is willing to consider the bay and its environs for national monument status. The bay certainly has as much national significance as San Juan National Historic Site which is administered by the National Park Service in Puerto 
Rico. Also deserving of protection is a comparable luminescent bay known as Puerto Mosquito at the neighbour island of Vieques.

A paper on 'The Galapagos Islands as an International Marine Park' was read for the late E. Yale Dawson, who concluded that, 'with careful regulation and responsible planning for the visiting public, the Galapagos Islands could be made the showplace for wildlife conservation unique among the existing and proposed marine parks of the world'. In a paper also read for him Dr Carleton Ray, of John Hopkins University, emphasised the need to put aside national interests and attempt to deal with marine resources at the international level. The symposium findings were ably summarised by Fred M. Packard.

Other marine parks in the Pacific besides those mentioned at the Congress include the Seventy Islands area off Eil Malk in the Palua Islands, set aside by the local legislature in 1956 as a completely protected marine preserve. These fascinating islets are interlaced with meandering channels that teem with a rich variety of reef and shore organisms, and they are sufficiently remote from Koror and other populated islands of the Palau group to cause no hardship to native fishermen. Nevertheless, violations have occurred which have not gone unpunished. In the Marshall Islands, in the south-western part of Eniwetok Atoll, and the adjacent reefs, five islets have been established as a wildlife reserve. This region is off limits to all persons except those of the Eniwetok Marine Biological Laboratory who are conducting scientific investigations.

Apparently no other marine parks exist in the vast Trust Territory of the Pacific Islands, but some certainly should be considered, such as Nan Madol of the lagoon of Ponape, a sort of submerged 'Micronesian Venice' consisting of 11 square miles of stone platforms and canals. The Territory of American Samoa is preparing an outdoor recreation plan which will identify several underwater park areas. In Tahiti and the other islands of French Polynesia there are no marine parks; however Governor Jean Sicurani has recently appointed a committee with the author as consultant, to recommend areas for consideration as reserves. Foremost among the sites favoured by the committee are the lovely reefs immediately in front of some resort hotels such as the Bali Hai Hotel in Moorea and the Hotel Bora Bora and Hotel Noa Noa in Bora Bora.

In Hawaii the first marine reserve was the reef surrounding little Coconut Island in Kaneohe Bay on windward Oahu, the location of the Hawaii Institute of Marine Biology; however, there have been problems concerning enforcement of this reserve. Lovely and much visited Hanauma Bay on Oahu, only a few minutes' drive from Honolulu, has at last been protected by the establishment, on October 23rd, 1967, of the Hanauma Bay Marine Life Conservation District, thanks to the persistent efforts of a number of conservationists, including Dr Ernst S. Reese. A survey by him and several graduate students of the University of Hawaii showed that 12 per cent of the visitors to the bay had been taking some form of life from the sea, thus materially lessening the enjoyment of the remaining 88 per cent. Also deserving of park status is Kealakekua Bay, on Hawaii's Kona coast, where there are some of the finest coral forma- 
tions in the islands, visited frequently by glass-bottom and other small boats. Not far to the south is the City of Refuge National Historic Park, administered by the National Park Service, where the author was pleasantly surprised to find attractive marine gardens and numerous reef fishes. There is as yet no jurisdiction over the marine zone, but a request was made of the 90th Congress to include it in the park. It has also been suggested that existing state beach parks, for which jurisdiction ends at the shore, should be extended into the sea where these marine sectors are worthy of conservation. This would obviate the need for land acquisition (some land area either adjacent to or near the marine part of a park is advisable to provide for public access and facilities); moreover, the machinery for park administration already exists and need only be modified to include the marine realm.

\section{Criteria for a Marine Park}

What is a marine park? Does it have to be mostly ocean to qualify for the name? I think not. Any park that includes part of the sea, regardless of land area, could be called a marine park, unless the marine portion is insignificant. To some persons the word park conveys the principal objective of recreation, to others it means primarily a reserve, but the two need not be incompatible. Visitors to a park can enjoy wild flowers without picking them and watch birds instead of shooting them. Similarly, coral gardens can be merely observed or photographed, and fishes watched and not speared. Large marine parks can be divided into sectors with recreation emphasised in some sectors and complete protection with minimal disturbance in others.

If a marine park is to be primarily recreational, it should be relatively near a centre of population so long as there is no risk of pollution from city growth or industrial development; if it is intended as a sanctuary or scientific study area the reverse would be the case. Areas where commercial or recreational activities such as fishing or water skiing are prevalent should be avoided especially when these would conflict with the park's objectives. Esthetic considerations such as the clarity of the water and the relative beauty and variety of the undersea landscape and resident animals and plants are, of course, of great importance in the selection of park sites. Safety for the visiting public is a prime consideration, for implicit in the term park is the feeling that the area is a safe one. A marine park invites the public to aquatic sports, so areas of heavy surf, strong current, or high tides should be avoided in setting up such parks. If there is danger visitors must be warned, and life-saving equipment supplied, there should be warnings of the presence of venomous, noxious, or dangerous marine organisms, and if possible steps taken to reduce their numbers. When man tampers with Nature, as by removing undesirable organisms, he often ends up worse off than before by disrupting the composition of the community. However, there would seem to be little risk in reducing the numbers of such animals as poisonous sea urchins of the genus Diadema, that may abound in shallow tropic seas, or of the many-armed IndoPacific starfish Acanthaster, which has venomous spines on the aboral surface, and is also undesirable because it feeds on coral; on the Great 
Barrier Reef it has become alarmingly common. Visitor centres, such as are found at the entrances to national parks and monuments and many state parks, where the public is familiarised with the attractions and possible hazards of the park, should also be provided.

For the marine scientists it is specially important to protect examples of all habitats in a marine park. A sand flat, mud bottom or mangrove swamp may hold little interest for the layman, but each is an ecosystem in itself and may be fascinating for the marine biologist. It can be important to the layman too, for not infrequently such seemingly uninviting areas serve as the nursery or feeding grounds for fish or other elements of the biota of other more attractive aquatic environments.

Marine sanctuaries are particularly important for research because they enable scientists to carry out ecological and other studies where man's disturbance of the environment and indigenous life is minimised or prevented. How, for example, can a scientist study the normal population of a marine community if the larger predators are removed by fishermen?

Some marine parks have been established which prohibit spearfishing but permit sport fishing with hook and line. This may be allowable in certain parts of a park, but it is important to eliminate it completely in the most attractive regions where snorkelers congregate. A fish is just as dead if caught by hook and line as with a spear, and a marine garden with a reduced fish population has lost some interest. Admittedly, spearfishing is more objectionable, because many fish are wounded and ultimately die. Moreover, fish soon become frightened of spearfishermen and hence all swimmers, so that the delightful experience of having colourful fishes approach you underwater, and view you with what seems the same curiosity that you watch them, is denied if spearfishermen have been there first.

Marine park boundaries should be set up in such a way that they are readily perceived, both by an approach from land and the open sea. A small island and its adjacent waters or a small bay are ideal in this respect, for their limits are obvious. It is not always possible, of course, to select such well-defined areas as parks, and buoys or other markers to fix the boundaries may be advisable.

The task of selling the idea of a marine park is made easier by stressing the advantages that it confers. First, the park level brings increasing recognition to the site and hence more visitors. The number of visitors to Buck Island rose from 600 in 1962, the first year of operation as a national monument, to 15,500 in 1965 , and today many persons are travelling to St Croix to see Buck Island who would not otherwise have come at all. Parks afford the opportunity to educate the visitors to appreciate what they see and become more aware of the need for conservation. The interests of divers can often be channelled into less destructive pursuits, such as under water photography; in California prizes have been given in diving competitions to those who collected the largest number of empty beer cans. It is not difficult to explain the function of a sanctuary to maintain breeding stocks of threatened marine organisms; the protected stocks, with large individuals of greater reproductive potential, then seed areas which are fully open to the public. 
Once a marine park has been inaugurated, the laborious task of enforcement begins. This is more complex than on land because of the need for transport on or within the water, the access by the boating public from the open sea, and the difficulty in observing the activities of divers on the sea bottom. Some parks started with no funds or personnel for enforcing regulations; in others the policing has been turned over to such agencies as a Division of Fish and Game, and the wardens and other staff may already be overworked. Marine parks need rangers just as much as terrestrial parks, to see that visitors adhere to park regulations and also to serve as guides and even naturalists.

At the present time, visitors to most marine parks view the marine gardens from glass-bottom boats, paddle boards or rubber mattresses with a transparent window forward, or as swimmers or divers. The two parks in the Virgin Islands have self-guiding, underwater trails. The dominant sessile organisms have identification markers on concrete blocks, with the label on an inclined face and the lettering large enough to be viewed from the surface, and protected with a glass plate that has to be cleaned at weekly intervals to remove fouling organisms. The trail at St John, about 100 metres long, starts on shore with a painted sign which tells the visitor how to use the trail, portrays the common fishes in colour, and warns against contact with the dark-coloured, long-spined sea urchin. The trail at Buck Island, which is further from land, has several floats for swimmers who may find the need for a resting place.

Other more radical ideas for visitors' observation in the sea have yet to be implemented, principally because of the cost and technical problems. One is an underwater tunnel with glass ports. Anchoring such a structure to the bottom in such a way that heavy seas would not detach it, providing for ventilation, and avoiding damage to the marine gardens it is designed to view, are all formidable tasks. And even if successfully in place, such a structure might alter the current pattern or otherwise change the marine environment so that corals or other marine organisms might die. Diving bells or fixed towers into which viewers descend by spiral stairways to look through glass ports at the bottom are other possibilities. Several such towers could be arrayed in a row, as along a reef front, and connected from top to top with a catwalk; they would be less apt to disturb the marine biota than a continuous structure on the bottom.

The most imaginative concepts for underwater viewing in comfort are submarines or underwater cable cars. Dr Jacques Piccard built a 40passenger tour submarine which was successfully operated in the Lake of Geneva to depths up to 310 metres in 1964, but this would be more difficult to do in the sea. Such craft would be costly and difficult to make completely safe, and to maintain. Nevertheless, they represent an irresistible ultimate goal in bringing the marine realm to the general public.

Recent progress in the development of marine parks is encouraging, but it is only a beginning. Hopefully the trend will continue so that the most outstanding marine gardens and reefs of the world will have the protection they deserve. 